Available online on 15.05.2020 at jddtonline.info
Open Access to Pharmaceutical and Medical Research
undestricted non-commercial use, provided the original work is properly cited

Open $\odot$ Access

Research Article

\title{
Formulation and Evaluation of Herbo-Mineral Facial Scrub
}

\author{
Mahajan Shraddha*, Gayakwad Devshree, Tiwari Abhilasha, Darwhekar G. N.
}

Acropolis Institute of Pharmaceutical Education and Research, Indore, M.P., India

\begin{abstract}
The main objective of present study was to prepare a herbo-mineral facial scrub. Majorly facial skin comes in direct contact of dirt, pollution, dust particles and having large number of dead cells. In order to remove the dead cells and make the skin healthy, cleaned an d nourished, some facial preparations required. The prepared scrub contains various natural ingredients which are safer for use and having fewer side effects and also they possess antiseptic, anti-infective, antioxidant, anti-aging and humectant properties. The scrub was prepared by using simple mixing method using various ingredients such as poppy seeds, neem extract, tulsi extract, aloe vera gel, almond oil, mixed in carbopol 934, rest of ingredients such as glycerin, triethanolamine, preservatives and perfuming agent were also added to this preparation with homogeneous mixing. The formulated scrub was evaluated for various parameters such as physical appearance, color, texture, odor, pH, visc osity, irritability, washability, homogeneity, extrudability, spreadability and found fruitful results for all the parameter tested. Thus the prepared formulation can be used effectively as it shows good scrubbing properties and it can be used to make a healthy, clean and glowing skin.
\end{abstract}

Keywords: Facial scrub, antiseptic, anti-aging, herbal, poppy seeds etc.

Article Info: Received 17 March 2020; Review Completed 29 April 2020; Accepted 06 May 2020; Available online 15 May 2020

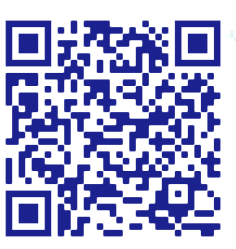

Cite this article as:

Mahajan S, Gayakwad D, Tiwari A, Darwhekar GN, Formulation and Evaluation of Herbo-Mineral Facial Scrub, Journal of Drug Delivery and Therapeutics. 2020; 10(3):195-197 http://dx.doi.org/10.22270/jddt.v10i3.4039

*Address for Correspondence:

Mahajan Shraddha, Acropolis Institute of Pharmaceutical Education and Research, Indore, M.P., India

\section{INTRODUCTION:}

Skin is the one of the largest organ of body. It serves as a major protective organ for other body parts. Skin functions as a protective wrapper, keeping everything beneath it and keep safe from daily threats such as the harsh effects of sun, wind and pollution germ filled grime $(\mathbf{1}, 2)$. The skin supports its own ecosystem of microorganism, including yeast and bacteria, which cannot be removes by any amount of cleaning. Skin is also a sensory organ, which indicates the health of individual. It is consists of material such as amino acid, lipid and carbohydrate etc. so that a balanced nutrition is required for skin to keep it glossy, clean and clear and healthy $(3,4)$. Cosmetics are defined as the products used for the purposes of cleansing, beautifying, promoting attractiveness or alternating the appearance (5). From the ancient time, different herbs are used for cleaning, beautifying and to manage them. Face skin is the major part of the body, which indicates the health of an individual (6). Skin care is very important to make it healthy and fresh; there are so many market preparations for skin care. Skin care is at the interface of cosmetics and dermatology but skin care differ from dermatology, it does not required any medical professional's every time (7).

Herbal exfoliates alleviate age- related changes and neutralize environmental attack by removing skin cells on the surface and stimulating cell growth in the sub-epidermal layer (8). As grow older, rate of cell turnover slows down dramatically. Majorly dead cell found on facial skin surface hang around much longer, a fact that tends to emphasize those fine lines and can make complexion dull and lifeless (9) To remain healthy and of good appearance, the skin surface requires frequent cleansing to remove grin, sebus and other secretions, dead cells, crusts and applied make-ups (10). By removing these dead skin cells exfoliating skin- whether physically with scrub using herbal products containing vitamins, antioxidants, antiseptics and anti-aging properties which help to deep cleanse the skin and make it glow and attractive.

\section{MATERIAL AND METHODS:}

Poppy seeds were purchased from local shop and then slightly crushed in pestle mortor. Extracts of neem and tulsi leaves were prepared using Soxhlet apparatus, neem and tulsi leaves kept with water for 72 hrs. separately. Extraction were dried and stored in desiccator for further use. Crushed poppy seeds dissolved in alcohol to avoid get swallow in water, fresh aloe vera leaves collected for gel preparation, from herbal garden of college. Other ingredients were almond oil, triethanolamine, preservatives, perfuming agent (Rose essence), carbopol 934 and glycerin. 
Table 1: Formula of Scrub

\begin{tabular}{|l|l|c|}
\hline \multicolumn{1}{|c|}{ Ingredients } & \multicolumn{1}{|c|}{ Uses } & Quantity \\
\hline Poppy seed & Scrubbing agent, antioxidant & $5-10 \%$ \\
\hline Camphor & Humectant, anti-aging agent & $0.25 \%$ \\
\hline Almond(Oil) & $\begin{array}{l}\text { Stimulate the production of new skin cells and smooth fine lines. } \\
\text { Emollients }\end{array}$ & $5 \%$ \\
\hline Glycerin & Emollients & $2.5-5 \%$ \\
\hline Kaolin & Adsorbent & $2.5 \%$ \\
\hline Neem (Extract) & Antiseptic, Skin conditioner & $1 \%$ \\
\hline Tulsi (Extract) & Anti-infective & $2.5 \%$ \\
\hline Aloe vera & Antioxidant & $1 \%$ \\
\hline Carbopol 934 & Thickening agent, Gelling agent & $0.05 \%$ \\
\hline Methyl paraben & Preservative & $0.025 \%$ \\
\hline Propyl paraben & Preservative & Q.S. \\
\hline Triethanolamine & Neutralizer & Q.S. \\
\hline Alcohol & Moisturizing & Q.S. \\
\hline Rose essence & Perfuming agent & Toke up to $50 \mathrm{~g}$ \\
\hline Demineralized water & Vehicle & $1 \%$ \\
\hline
\end{tabular}

\section{Method of Preparation:}

\section{* Collection of Plant Material}

Identified fresh leaves of plants were collected from herbal garden of Acropolis Institute of Pharmaceutical Education \& Research College, Indore.

\section{Preparation of Extract:}

Preparation of Neem Extract: Neem extract was prepared by using Soxhlet apparatus. neem leaves kept with water for $72 \mathrm{hrs}$. Extraction was dried and stored in desiccator for further use.

Preparation of Tulsi Extract: Tulsi extract was prepared by using Soxhlet apparatus. Tulsi leaves kept with water for 72 hrs. Extraction was dried and stored in desiccator for further use.

\section{Preparation of Aloe-vera Gel:}

Fresh aloe vera leaves collected and remove the gel manually. Gel was grinded into mixer to get a homogeneous form.

\section{Preparation of Carbopol Base:}

Required quantity of carbapol 934 taken in a separate beaker. Add rest of ingredient one by one in to it with continuous and homogeneous stirring.

Step 1- Mixed camphor, almond oil, glycerin and propyl paraben together in a separator beaker.

Step 2- Mixed crushed Poppy seed (pre alcohol mixed), kaolin, neem extract, tulsi extract, aloe vera gel and methyl paraben in another container.

Step 3- Add carbopol in little quantity of alcohol, add aloe vera gel in the mixture and triturate well in pestle mortar.
Add the contents of steps 1, 2 into 3 with gentle continuous stirring in a pestle mortar. Add demineralized water gradually till a semi solid consistency preparation was not formed.

\section{Evaluation parameter of Facial Scrub-}

Formulation was tested for physical appearance, color, texture, odor, $\mathrm{pH}$, viscosity, irritability, washability, homogeneity, extrudability and spreadibility $(\mathbf{1 1}, \mathbf{1 2}, \mathbf{1 3}, \mathbf{1 4})$.

\section{Organoleptic properties-}

A) Colour- The color of formulation was checked manually and observed as creamish white.

B) Odour- The smell of formulation was checked by applying preparation on hand and feels the fragrance of perfume.

C) Consistency- The consistency of the formulation and particles were used to check the texture and homogeneity of preparation on the skin such as stiffness, grittiness, greasiness effect. Preparation found semi-solid in nature.

D) Homogeneity and texture- It was tested by pressing a small quantity of the formulated scrub between the thumb and index finger.

2. Washability- This test was performed directly on skin, preparation applied on skin and wash with normal water, after washing clean and clear skin observed.

3. pH- $\mathrm{pH}$ of $1 \%$ aqueous solution of formulation was measured by using a calibrated digital $\mathrm{pH}$ meter and result found 7.5

4. Viscosity- For Viscosity measurement, Brookfield viscometer "Helepath Spindle A-91 used, and result observed as 6960-7100cps at $10 \mathrm{rpm}$. 
5. Extrudability- It is usual empirical test to measure the force required to extrude the material from tube. More quantity extruded, better the extrudability. The formulation under study was filled in a clean, aluminum collapsible tube with nozzle tube of $5 \mathrm{~mm}$ opening and applies pressure on tube by the help of finger. Tube extrudability was then determined by measuring amount of formulation extruded through the tip when the pressure was applied on tube.

6. Spreadability- Spreadability of the formulations was determined by measuring the spreading diameter by keeping $1 \mathrm{~g}$ of sample between two horizontal glass plates $(10 \mathrm{~cm} \times 20 \mathrm{~cm})$. The standard weight $20 \mathrm{gm}$ applied on the upper glass plate. The spreading quality checked by visual inspection.

7. Skin irritation- Small quantity of the preparation was applied on the dorsal part of hand and kept for few minutes and found to be non-irritant, No redness and edema or any other adverse effect.

\section{RESULTS AND DISCUSSION:}

Table 2: Evaluation of Scrub

\begin{tabular}{|l|l|l|}
\hline $\begin{array}{l}\text { N. } \\
\text { N. }\end{array}$ & Parameters & Observation \\
\hline 1 & Colour & Creamish white \\
\hline 2 & Odour & Characteristic as Rose \\
\hline 3 & Consistency & Good \\
\hline 4 & $\begin{array}{l}\text { Homogeneity } \\
\text { and texture }\end{array}$ & Good \\
\hline 5 & Washability & Easily washable \\
\hline 6 & pH & 7.5 \\
\hline 7 & Viscosity & $6960-7100$ cps at $10 \mathrm{rpm}$ \\
\hline 8 & Extrudability & Easily extruded \\
\hline 9 & Spreadability & Easily spread \\
\hline 10 & Skin Irritation & Non Irritant \\
\hline
\end{tabular}

The formulated herbo-mineral scrub was evaluated at different parameters. All the organoleptic properties were checked visually such as colour, odour, consistency, homogeneity and texture. As a result, colour observed as creamish white, no bad smell occurred from formulation. The consistency of the formulation found suitable as required to apply on skin. Particles were used to check for the texture and homogeneity of preparation on skin found good and satisfactorily as the preparation show grittiness, greasiness properties on skin. Washability properties found good, as it is easily removed by washing with normal water. $\mathrm{pH}$ of the formulation checked and found 7.5 means suitable for skin. Extrudability test performed with the help of empty collapsible tube filled with scrub, checked for quantity extruded from the nozzle of $5 \mathrm{~mm}$ and found satisfactory. Spreadabilty quality also tested with the help of glass plates and found that preparation having good consistency and easily spreadable. No irritation, redness, edema and any dermatological effects observed on skin. Viscosity checked and result found as $6960-7100 \mathrm{cps}$ at $10 \mathrm{rpm}$.

\section{CONCLUSION:}

From the above results it is concluded that new formulation herbo-mineral scrub can be safe to use and the poppy seed used as a scrubbing/cleansing agent showing good effects and as mostly ingredients are natural ingredients so chances for side effects are less. It can be used for any type of skin i.e. normal, oily and dry. It gives best results and make the skin glowing and healthy.

\section{REFERENCES:}

1. Prathyusha J, Yamani NS, Santhosh G, Aravind A, Naresh B, Formulation and Evaluation of Polyherbal Face Scrubber for Oily Skin in Gel Form, International Journal of Pharmaceutical Sciences and Drug Research 2019;11(4):126-128.

2. Debbarma D, Moharana PK, Mishra B, Ramana V and Dimple W. Clinical review of deep cleansing apricot scrub: an herbal formulation. International Journal of Bioassay. 2015; 4(9):4251-253.

3. Darsika SKV, Grace CXF and Shanmuganathan S. Formulation and Evaluation of a polyherbal face wash gel WJPPS, 2015; 4(06):585-588.

4. Sharma PP, Cosmetics-formulation, manufacturing and quality control. 3rd Edition Delhi: Vandana Publication: 2005 Page 638.

5. Shoba Rani R; Hiremanth. Text book of Industrial pharmacy, Drug delivery systems \& Cosmetics \& Herbal drug technology: Universities press (India) Ltd; 2nd Edition.

6. Okereke J N, Udebuani AC, Ezeji EU, Obasi KO, Nnoli MC. Possible Health Implications Associated with Cosmetics: A Review, Science journal Public Health 2015; 3(5-1):58-63.

7. Mary P. Lupo. Antioxidants and Vitamins in Cosmetics. Clinical Dermatology 2001; 19:467-473.

8. Nilani Packianathan, Ruckmani Kandasamy, Skin Care with Herbal Exfoliants, Functional Plant Science and Biotechnology 5 (Special Issue 1), 94-97 (C)2011 Global Science Books.

9. Aglawe SB, Gayke AU, Khurde A, Mehta D, Mohare T, Pangavane A, Kandalkar S, Preparation and evaluation of polyherbal facial scrub. Journal of Drug Delivery and Therapeutics. 2019; 9(2):61-63

10. Nemade CT, Baste N. formulation and evaluation of a herbal facial scrub, World Journal of Pharmaceutical Research 3(3):4367-4371.

11. Fuizz and C. Richard, 2012.Transdermal delivery system. US Patent 5736154

12. Guy RH, Current Status and future prospects of Transdermal Drug Delivery, Pharmacy Research, 1996; 13:1765-1769.

13. Jain A, Deveda P, Vyas N, Chauhan J. Development of Antifungal Emulsion Based Gel for topical fungal infection, International Journal of Pharma Research and Development, 2003; 2(12):18-19.

14. Bhanu PV, Shanmugam and Lakshmi PK. Development and Optimization of Novel Diclofenac Emulgel for Topical Drug Delivery. International Journal of Comprehensive Pharmacy, 2011; 9(10):1-4. 